\title{
Female Reproductive System Cancer TNM Finding v8
}

National Cancer Institute

\section{Source}

National Cancer Institute. Female Reproductive System Cancer TNM Finding v8. NCI

Thesaurus. Code C139589.

A finding about one or more characteristics of female reproductive system cancer, following the rules of the TNM AJCC V8 classification system. The TNM categories have been defined to correspond to the FIGO stages. Some amendments have been made in collaboration with FIGO, and the classifications now published have the approval of FIGO, AJCC, and all other national T NM committees of the Union for International Cancer Control (UICC). (from AJCC 8th Ed.) 